\title{
Efisiensi Penggunaan Dana Bantuan Pemda NTT melalui Program Anggur Merah Bagi Kelompok Usaha Produktif di Kelurahan Maubeli, Kecamatan Kota Kefamenanu, Kabupaten Timor Tengah Utara
}

Dominikus Kopong Duli ${ }^{a}$

${ }^{a}$ Fakultas Ekonomi dan Bisnis, Universitas Timor, Kefamenanu, Indonesia.

\section{Article Info}

Article history:

Received 27 Januari 2016

Received in revised form 4 Maret 2016

Accepted 11 Mei 2016

\section{Keywords:}

Efisiensi Penggunaan Dana

Anggur Merah

Maubeli

Usaha Produktif

\section{Abstrak}

Tujuan dari penelitian ini adalah untuk mengetahui pengaruh pengeluaran terhadap penerimaan dan laba/rugi bagi kelompok usaha penerima bantuan Program Anggur Merah di Kelurahan Maubeli. Jika pengeluaran lebih kecil dari penerimaan maka kelompok memperoleh keuntungan. Sebaliknya pengeluaran lebih besar dari penerimaan maka kelompok menderita kerugian. Hasil penelitian menunjukan bahwa dari lima belas kelompok yang memanfaatkan dana bantuan, sebanyak tujuh kelompok (46,67\%) masuk dalam kategori efisien karena memperoleh keuntungan. Sedangkan delapan kelompok lainnya $(53,33 \%)$ menderita kerugian. Ada beberapa kelopompok usaha yang cukup produktif dalam memanfaatkan modal bantuan. Kelompok yang memperoleh keuntungan lebih besar sepuluh juta setahun berjumlah 2 kelompok $(28,57 \%)$. Kelompok yang memperoleh keuntungan lima juta, namun lebih kecil sepuluh juta berjumlah 2 kelompok (28,57\%). Kelompok yang memperoleh keuntungan lebih besar satu juta, namun di bawah lima juta berjumlah 3 kelompok $(42,86 \%)$. Hasil penelitian ini juga menunjukan bahwa ada delapan kelompok usaha yang kurang beruntung atau mengalami kerugian. Kelompok yang mengalami kerugian di atas sepuluh juta berjumlah 2 kelompok (25\%), sedangkan kelompok yang mengalam kerugian diatas 5 juta namun di bawah 10 juta, berjumlah 3 kelompok (37,5\%). Sedangkan kelompok yang mengalami kerugian diatas 1 juta namun dibawa lima juta berjumlah 3 kelompok (37,5\%). (22016 dipublikasikan oleh Agrimor.

\section{Pendahuluan}

Kelurahan Maubeli adalah salah satu kelurahan di Kecamatan Kota Kefamenanu, Kabupaten Timor Tengah Utara dengan wilayahnya seluas : 4,00 $\mathrm{km}^{2}$. Penduduknya berjumlah : 4560 Jiwa, tersebar didalam : 1014 kepala keluarga (Data Kelurahan Maubeli bulan Februari 2014).

Mata pencaharian penduduknya beraneka- ragam; ada yang bekerja sebagai Pegawai Negeri Sipil (PNS), TNI/POLRI, pegawai swasta, kontraktor, tukang kayu, tukang batu, buru bangunan, pedagang, petani dan lain-lain. Sebagian besa penduduk didominasi oleh para petani, dan pertukangan. Pendapatan perkapita penduduk rata-rata Rp 673.128,-- per tahun (BPS dan BAPPEDA Kab. TTU, 2005).

Pada tahun Anggaran 2011/2013, pemerintah Propinsi Nusa Tenggara Timur menyalurkan bantuan melalui program Desa/Kelurahan Mandiri Anggur Merah (DEMAM) bagi masyarakat Nusa Tenggara Timur. Program in dikukuhkan dengan Peraturan Gubernur Nusa Tenggara Timur Nomor 33 Tahun 2010.

Kelurahan Maubeli, termasuk salah satu kelurahan di Kota Kefamenanu yang mendapat bantuan program tersebut. Program ini diharapkan dapa meningkatkan pendapatan yang pada sasaran akhirnya adalah meningkatkan kesejahteraan masyarakat itu sendiri. Sasaran bantuan adalah masyarakat yang berpendapatan menengah ke bawah, antara lain : petani, tukang kayu, tukang batu, buruh bangunan, ojek dan lainnya. Teknis pemberian bantuan dilakukan dengan cara menghimbau, mengarahkan masyarakat agar dengan kesadaran sendiri membentuk kelompok usaha produktif. Kelompok usaha tersebut dikelola secara kolektif dengan semangat gotong royong sebagai cermin nafas kebersamaan dalam masyarakat Indonesia.

Kelompok penerima bantuan yang dibentuk berjumlah 15 (lima belas) buah dengan jumlah anggota seluruhanya sebanyak 91 (Sembilan puluh satu orang yang tersebar di 15 (lima belas) Rukun Tetangga (RT). Jumlah bantuan yang diberikan bervariasi mulai dari Rp 10.000.000,- (lima juta Rupiah) sampa dengan Rp 35.000.000,- (tiga puluh lima juta Rupiah) untuk setiap kelompoknya. Dana bantuan tersebut akan bergulir setelah dikelola oleh kelompok yang dipercayakan selama kurang lebih satu tahun.

Teknis pemberian bantuan dilakukan oleh tim kelurahan yang dibentuk dan dipercayakan untuk itu. Sebelum memberikan bantuan tim terlebih dahulu melakukan seleksi administrasi yang diajukan oleh kelompok. Setelah setesa melaksanakan tugas seleksi, tim melakukan verifikasi lapangan untuk mendapatkan kesesuaian data antara berkas administrasi yang diajukan dengan kondisi riil di lapangan. Tim ini mempunyai kewenangan untuk menetapkan kelayakan kelompok untuk menerima bantuan tersebut

Kelompok yang dinyatakan layak menerima bantuan berhak menerimanya. Dana bantuan tersebut, diharapkan dapat dikelola sebaik-baiknya (efektif dan efisien). Efektif artinya penggunaan dana bantuan sesuai dengan rencana kegiatan usaha. Sedangkan efisien artinya pengelolaan dana harus bisa mendatangkan keuntungan bagi kelompok dan masyarakat sekitarnya. Apabila pengelolaannya secara baik dan memberikan manfaat bagi peningkatan pendapatan maka program bantuan ini dapat dikatakan bermanfaat. Sebaliknya jika tidak dikelola secara baik maka program bantuan ini menjadi sia-sia dan terkesan hanya menghamburkan uang negara.

Usaha-usaha produktif yang dijalankan oleh kelompok bervariasi. Setiap kelompok menggeluti usahanya masing mengikuti kesepakatan bersama sesua perencanaan awal usaha. Ada yang bergerak dalam bidang usaha pertanian menanam saayur-sayuran; bidang peternakan : beternak sapi, babi, ayam, kambing; bidang perdagangan : usaha perkiosan, jual beli hewan, pemotongan hewan, jual beli sayur mayur; ikan, daging dan lain-lain; bidang usaha home industri : tenun ikat, mebeler, batu bata dan lain-lainnya.

Dalam menjalankan kegiatan usaha kelompok sebagaimana tersebut di atas, senantiasa diawasi dan didampingi oleh tim dari kelurahan dan propinsi, untuk memberikan motivasi dan dukungan moril seperti pengarahan, koreksi kegiatan agar tidak menyimpang dari rencana awalnya. Dengan demikian anggota kelompok lebih terpacu semangatnya untuk terus bekerja, berusaha dan mendapatkan manfaat dari bantuan pemerintah tersebut. Sasaran akhir dari bantuan pemerintah ini adalah meningkatkan kesejahteraan masyarakat secara keseluruhan. Oleh karena itu dana bantuan tersebut sifatnya bergulir untuk seluruh lapisan masyarakat yang tergolong dalam kelompok ekonomi lemah.

Pemanfaatan dana bantuan pemerintah ini dimaksudkan untuk usaha-usaha yang sifatnya produktif dan tidak untuk konsumtif. Produktif artinya dana yang dikelola oleh masing-masing kelompok diharapkan bertambah karena adanya keuntungan/laba yang diperoleh. Keuntungan/laba yang diperoleh tidak seharusnya dikonsumsi habis melainkan dapat diintensifikasikan menjadi modal usaha. Hal ini dilakukan untuk mengantisipasi pengembalian modal bantuan untuk digulirkan kepada masyarakat/kelompok lain yang baru dibentuk. Sifa konsumtif anggota kelompok seharusnya dihindari agar tidak menimbulkan deficit modal pada suatu periode tertentu. Sifat konsumtif anggota kelompok dengan mengabaikan criteria penggunaan apalagi menonjolkan sikap tidak peduli dengan orang lain juga dapat menimbulkan kecemburuan satu sama lain. Hal ini juga dapat menimbulkan persoalan dalam upaya mewujudkan program pemerintah tersebut

Berdasarkan beberapa informasi yang berkembang, bahwa tidak semua usaha kelompok, berjalan sesuai dengan rencana dan harapan. Beberapa kelompok mengalami kendala yang mengakibatkan tersendatnya pengembalian dana bantuan. Kendala yang dihadapi seperti : usaha sayur mayur yang gagal panen, hewan ternak yang terserang penyakit, kurangnya kesadaran anggota kelompok untuk mengembalikan dana bantuan dan lain-lain kendala. Walaupun menghadapi kendala namun upaya pengembalian tetap ada. Hal ini terindikas dari adanya cicilan/angsuran dari kelompok pengguna bantuan ada yang sudah mencapai $100 \%$; namun pengembaliannya masih ada kelompok yang hanya berkisar pada angka 7\%-10\% dari total bantuan yang diterima (Laporan Pendamping).

Memang dalam kegiatan usaha selalu ada rintangan atau hambatan namun sebagian besar kelompok dapat melaksanakan usahanya dengan baik. Ada kesadaran dalam upaya pengembangan usaha. Hal ini dapat terlihat dari adanya komitmen kelompok untuk meraih keuntungan yang dapat memberikan perubahan dalam kehidupan rumah tangga mereka masing-masing. Anggota kelompok saling berdiskusi, memberikan masukan mengenai hal-hal strategis untuk dijalankan bersama guna mencapai tujuan bersama.

Dalam kaitan pemanfaatan dana, aktivitas usaha kelompok perlu dievaluasi untuk mengetahui apakah usahanya itu dapat memberikan penghasilan yang signifikan ataukah sebalikya. Penghasilan yang diterima harus lebih besar agar bisa diperoleh surplus penerimaan yang disebut keuntungan. Dalam kondisi yang lain penghasilan harus bisa menutup biaya atau modal yang digunakan tetapi tidak ada surplus penerimaan . Keadaan ini sering disebut titik impas/pulang pokok. Secara sederhana dapat dikatakan bahwa apabila penghasilan lebih besar maka usaha kelompok memperoleh laba/keuntungan. Sebaliknya jika penghasilan lebih kecil maka kelompok usaha menderita kerugian.

Kondisi ekonomi keluarga masing-masing anggota kelompok juga perlu ada peningkatan. Pendapatan sebelumnya relatif kecil, diharapkan setelah adanya dana bantuan terjadi peningkatan. Kelompok yang sebelumnya tidak memilki hewan piaraan setelah menerima bantuan masing-masing memiliki hewan piaraan. Sebelumya anggota kelompok tidak memiliki usaha produktif, setelah adanya bantuan muncul usaha-usaha produktif dari kelompok penerima bantuan. Dengan adanya peningkatan ekonomi keluarga maka kebutuhan untuk membiayai pendidikan anak, kesahatan, rehabilitasi tempat tinggal dan kebutuhan rumah tangga lainnya bisa teratasi. Dalam jangka panjang apabila usaha produktif kelompok dikelola secara serius maka dengan sendirinya memberikan dampak ekonomi yang lebih luas tidak hanya pada anggota kelompok tapi juga bagi masyarakat banyak. 


\section{Metode}

Penelitian dilaksanakan di Kelurahan Maubeli dengan sasaran penelitian adalah Kelompok Usaha Produktif yang menggunakan dana bantuan Pemerintah Propinsi

Nusa Tenggara Timur melalui Program Anggur Merah, penelitian ini membutuhkan waktu kurang lebih selama 1 bulan yakni pada bulan Maret 2014 Sumber data dalam penelitian ini adalah data primer yakni himpunan keterangan yang diperoleh langsung dari kelompok usaha (pengguna dana bantuan). Selain data primer, data sekunder juga digunakan dalam penelitian ini antara lain catatan - catatan pengeluaran, penerimaan serta keuntungan kelompok.

Dalam penelitian ini populasi yang digunakan adalah keseluruhan kelompok usaha produktif yang menggunakan dana bantuan Pemerintah Daerah Nusa Tenggara Timur, melalui Program Desa Mandiri/Kelurahan Anggur Merah. Kelompok objek dimaksud berjumlah 15 kelompok yang tersebar di seluruh Rukun Tetangga (RT) kelurahan Maubeli, kecamatan Kota Kefamenanu, oleh karena itu penelitian ini tidak menggunankan sampel.

Pengumpulan data menggunakan beberapa teknik/ metode antara lain 1) wawancara yaitu pengumpulan data dengan melakukan wawancara langsung dengan para pengurus kelompok, baik dari ketua ataupun anggota; 2) kuesioner adalah serangkaian pertanyaan yang ditujukan kepada masing-masing kelompok dalam bentuk daftar pertanyaan dan harus diisi dengan penuh tanggung jawab dan; 3) dokumentasi adalah pengumpulan data melalui dokumen-dokumen yang sudah terhimpun tercatat oleh tiap-tiap kelompok. Hasil penelitian dianalisis dengan metode analisis deskriptif yakni mendeskripsikan data dalam bentuk narasi, table, untuk menjelaskan hasil penelitian.

\section{Hasil dan Pembahasan}

\subsection{Analisis Karakteristik Kelompok Usaha}

Berdasarkan hasil penelitian yang dilaksanakan pada 15 kelompok usaha pengguna dana bantuan pemerintah Propinsi Nusa Tenggara Timur, dapat dideskripsikan sebagai berikut :

Tabel 1. Data Nama Kelompok Usaha, Jumlah Anggota, dan Jenis Usaha

\begin{tabular}{clclr}
\hline No & Nama Kelompok & $\begin{array}{c}\text { Jumlah anggota } \\
\text { (Orang) }\end{array}$ & Jenis Usaha & $\begin{array}{c}\text { Jumlah Bantuan } \\
(\mathrm{Rp})\end{array}$ \\
\hline 1 & Gemilang & 5 & Simpan Pinjam & $10.000 .000,-$ \\
2 & Sabar Subur & 7 & Penggemukan Sapi & $30.000 .000,-$ \\
3 & Jaya Neonbat & 5 & Ayam Potong & $20.000 .000,-$ \\
4 & Sadi Sodak & 5 & Penggemukan Babi & $20.000 .000,-$ \\
5 & Moenfeu & 5 & Daging Sei & $12.000 .000,-$ \\
6 & Hidup Baru & 6 & Meubeler & $15.000 .000,--$ \\
7 & Tani Mandiri & 7 & Holtikultura & $26.250 .000,-$ \\
8 & Mekar Sari & 5 & Pengadaan kayu & $10.500 .000,--$ \\
9 & Nekmese & 10 & Paronisasi & $35.000 .000,-$ \\
10 & Vatikan & 4 & Simpan Pinjam & $10.000 .000,-$ \\
11 & Mekar Pangan & 5 & Warung /kios & $10.000 .000,-$ \\
12 & Besahoma & 4 & Tenun Ikat & $10.000 .000,-$ \\
13 & Seruni & 5 & Simpan Pinjam & $10.000 .000,--$ \\
14 & Tafenkuan & 5 & Simpan Pinjam & $15.000 .000,-$ \\
15 & Mawar Saron & 6 & Simpan Pinjam & $15.000 .000,-$ \\
\hline Jumlah & 85 & & $248.750 .000,--$ \\
\hline
\end{tabular}

Sumber : Data Primer Diolah, 2014.

Tabel 1. menunjukan bahwa Dana Bantuan Pemerintah Propinsi Nusa Tenggara Timur yang digulirkan kepada lima belas kelompok usaha melalui program Demam Anggur Merah, dapat memberdayakan masyarakat di kelurahan Maubeli sebanyak 85 (delapan puluh lima) orang. Para anggota kelompok berkreasi dan bersepakat untuk membuka usaha-usaha produktiif, guna membantu meningkatkan kesejahteraan hidup masing-masing.

Tabel 2. Data Jumlah Bantuan, Pengeluaran dan Sisa Dana

\begin{tabular}{clccc}
\hline No Nama Kelompok & $\begin{array}{c}\text { Jumlah Bantuan } \\
(\mathrm{Rp})\end{array}$ & $\begin{array}{c}\text { Pengeluaran } \\
(\mathrm{Rp})\end{array}$ & $\begin{array}{c}\text { Dana yang tidak } \\
\text { Digunakan }\end{array}$ \\
\hline 1 & Gemilang & $10.000 .000,-$ & $10.000 .000,-$ & 0 \\
2 & Sabar Subur & $30.000 .000,-$ & $28.000 .000,-$ & $2.000 .000,-$ \\
3 & Jaya Neonbat & $20.000 .000,-$ & $20.000 .000,-$ & 0 \\
4 & Sadi Sodak & $20.000 .000,-$ & $20.000 .000,-$ & 0 \\
5 & Moenfeu & $12.000 .000,-$ & $12.000 .000,-$ & 0 \\
6 & Hidup Baru & $15.000 .000,-$ & $15.000 .000,-$ & 0 \\
7 & Tani Mandiri & $26.250 .000,-$ & $26.250 .000,-$ & 0 \\
8 & Mekar Sari & $10.500 .000,-$ & $10.500 .000,-$ & 0 \\
9 & Nekmese & $35.000 .000,-$ & $35.000 .000,-$ & 0 \\
10 & Vatikan & $10.000 .000,-$ & $3.000 .000,-$ & $7.000 .000,-$ \\
11 & Mekar Pangan & $10.000 .000,-$ & $8.500 .000,-$ & $1.500 .000 .-$ \\
12 & Besahoma & $10.000 .000,-$ & $7.980 .000,-$ & $2.020 .000,-$ \\
13 & Seruni & $10.000 .000,-$ & $10.000 .000,-$ & 0 \\
14 & Tafenkuan & $15.000 .000,-$ & $15.000 .000,-$ & 0 \\
15 & Mawar Saron & $15.000 .000,-$ & $15.000 .000,-$ & 0 \\
\hline Jumlah & $248.750 .000,-$ & $236.230 .000,-$ & $12.520 .000,-$ \\
\hline Sumber $:$ Data Primer Diolah & 2014 & &
\end{tabular}

Sumber : Data Primer Diolah, 2014.

Usaha produktif yang dilaksanakan oleh kelompok masyarakat bahwa usaha yang paling banyak disukai adalah simpan pinjam sebanyak 5 kelompok
$(33,33 \%)$, penggemukan sapi sebanyak 3 kelompok (20\%), peternakan ayam potong berjumlah, Daging Sei, Meubeler, Holtikultura, Pengadaan kayu, Warung/kios, Tenun ikat, masing-masing 1 kelompok $(46,67 \%)$.

Tabel 2. di atas menunjukan bahwa total dana yang digulirkan untuk lima belas kelompok usaha berjumlah $\mathrm{Rp} 248.750 .000$,- (dua ratus empat puluh delapan juta tujuh ratus lima puluh ribu rupiah). Dana bantuan yang digunakan untuk usaha sebesar R p 263.230.000,- (dua ratus enam puluh tiga juta dua ratus tiga puluh ribu rupiah) atau $94,97 \%$. Hal ini berarti bahwa masih ada dana yang belum digunakan sebesar Rp 12.520.000,- (dua belas juta lima ratus dua puluh ribu rupiah) atau 5,03\%. Kelompok yang menggunakan dana bantuan seluruhnya $(100 \%)$ sebagai modal usaha/pengeluaran sebanyak 11 kelompok $(73,33 \%)$ Sedangkan kelompok yang tidak menggunakan dana bantuan seluruhnya sebagai modal usaha sebanyak 4 kelompok $(26,67 \%)$.

Tabel 3. Data Pengeluaran, Pendapatan, dan Laba /Rugi Kelompok Usaha

\begin{tabular}{clccc}
\hline No & Nama Kelompok & Pengeluaran & Pendapatan & Laba/(Rugi) \\
\hline 1 & Gemilang & $10.000 .000,-$ & $44.000 .000,-$ & $34.000 .000,-$ \\
2 & Sabar Subur & $28.000 .000,-$ & $35.000 .000,-$ & $7.000 .000,-$ \\
3 & Jaya Neonbat & $20.000 .000,-$ & $13.000 .000,-$ & $(7.000 .000)$ \\
4 & Sadi Sodak & $20.000 .000,-$ & $24.000 .000,-$ & $4.000 .000,-$ \\
5 & Moenfeu & $12.000 .000,-$ & $5.000 .000,-$ & $(7.000 .000)$ \\
6 & Hidup Baru & $15.000 .000,-$ & $4.040 .000,-$ & $(10.960 .000)$ \\
7 & Tani Mandiri & $26.250 .000,-$ & $4.000 .000,-$ & $(22.250 .000)$ \\
8 & Mekar Sari & $10.500 .000,-$ & $17.200 .000,-$ & $6.700 .000,-$ \\
9 & Nekmese & $35.000 .000,-$ & $50.000 .000,-$ & $15.000 .000,-$ \\
10 & Vatikan & $3.000 .000,-$ & 1.500 .000 & $(1.500 .000)$ \\
11 & Mekar Pangan & $8.500 .000,-$ & $9,700.000,-$ & 1.200 .000 \\
12 & Besahoma & $7.980 .000,-$ & $7.700 .000,-$ & $(280.000)$ \\
13 & Seruni & $10.000 .000,-$ & $8.646 .000,-$ & $(1.354 .000)$ \\
14 & Tafenkuan & $15.000 .000,-$ & $9.050 .000,-$ & $(5.950 .000)$ \\
15 & Mawar Saron & $15.000 .000,--$ & $16.500 .000,-$ & $1.500 .000,-$ \\
\hline Jumlah & $248.750 .000,-$ & $236.230 .000,-$ & $13.106 .000,-$ \\
\hline Sumber $:$ Data Primer Diolah & & &
\end{tabular}

Sumber : Data Primer Diolah, 2014.

Tabel 3. di atas menunjukan bahwa rata-rata pengeluaran kelompok sebesar Rp 15.748.666,7 . Sedangkan pendapatan rata-rata sebesar Rp dari lima belas kelompok yang menjalan usaha, tidak semua kelompok memperoleh keuntungan, melainkan sebagian menderita kerugian. Kelompok usaha yang memperoleh keuntungan atau laba berjumlah 7 kelompok (46,67\%). Sedangkan jumlah kelompok usaha yang mengalami kerugian sebanyak 8 kelompok $(53,33 \%)$.

$\underline{\text { Tabel 4. Data Pengeluaran, Pendapatan dan Laba Kelompok Usaha }}$

\begin{tabular}{clccc}
\hline No & $\begin{array}{c}\text { Nama } \\
\text { Kelompok }\end{array}$ & Pengeluaran & Pendapatan & Laba \\
\hline 1 & Gemilang & $10.000 .000,-$ & $44.000 .000,-$ & $34.000 .000,-$ \\
2 & Sabar Subur & $28.000 .000,-$ & $35.000 .000,-$ & $7.000 .000,-$ \\
3 & Sadi Sodak & $20.000 .000,-$ & $24.000 .000,-$ & $4.000 .000,-$ \\
4 & Mekar Sari & $10.500 .000,-$ & $17.200 .000,-$ & $6.700 .000,-$ \\
5 & Nekmese & $35.000 .000,-$ & $50.000 .000,-$ & $15.000 .000,-$ \\
6 & Mekar Pangan & $8.500 .000,-$ & $9,700.000,-$ & 1.200 .000 \\
7 & Mawar Saron & $15.000 .000,-$ & $16.500 .000,-$ & $1.500 .000,-$ \\
\hline Jumlah & $127.000 .000,-$ & $196.400 .000,-$ & $69.400 .000,-$ \\
\hline
\end{tabular}

Sumber : Data Primer Diolah, 2014.

Tabel 4. di atas menunjukan bahwa kelompok Usaha yang memperoleh keuntungan berjumlah 7 kelompok. Total pengeluaran Rp 127.000.000,- (seratus dua puluh tujuh juta rupiah. Rata-rata pengeluaran tiap kelompok Rp 18.142.850,- (delapan belas juta seratus empat puluh dua ribu delapan ratus lima puluh rupah).Total pendapatan berjumlah Rp 196.400.000,- (seratus Sembilan puluh enam juta empat ratus ribu rupiah). Rata-rata pendapatan tiap kelompok Rp 24.200.000,-(dua puluh empat juta dua ratus ribu rupiah). Rasio pendapatan dibandingkan dengan penggunaan modal bantuan sebesar 1 : 15,4 (154.65\%). Hal ini memiliki pengertian bahwa setiap Rp 1 dikeluarkan untuk membiayai usaha dapat memberikan pendapatan sebesar Rp 15,40 (lima belas koma empat puluh rupiah. Keuntungan yang diperoleh sebesar Rp 69.400.000,-(enam puluh sembilan juta empat ratus ribu rupiah). Rasio keuntungan $1: 5,4$ (54,65\%). Hal ini memiliki pengertian bahwa setiap Rp 1 yang dikeluarkan dapat memberikan keuntungan/laba sebesar Rp 5,46,-(lima koma empat puluh enam rupiah).

$\underline{\text { Tabel 5. Data Pengeluaran, Pendapatan dan Rugi Kelompok Usaha }}$

\begin{tabular}{clccc}
\hline No & $\begin{array}{c}\text { Nama } \\
\text { Kelompok }\end{array}$ & Pengeluaran & Pendapatan & Rugi \\
\hline 1 & Jaya Neonbat & $20.000 .000,-$ & $13.000 .000,-$ & $(7.000 .000)$ \\
2 & Moenfeu & $12.000 .000,-$ & $5.000 .000,-$ & $(7.000 .000)$ \\
3 & Hidup Baru & $15.000 .000,-$ & $4.040 .000,-$ & $(10.960 .000)$ \\
4 & Tani Mandiri & $26.250 .000,-$ & $4.000 .000,-$ & $(22.250 .000)$ \\
5 & Vatikan & $3.000 .000,-$ & 1.500 .000 & $(1.500 .000)$ \\
6 & Besahoma & $7.980 .000,-$ & $7.700 .000,-$ & $(280.000)$ \\
7 & Seruni & $10.000 .000,-$ & $8.646 .000,-$ & $(1.354 .000)$ \\
8 & Tafenkuan & $15.000 .000,-$ & $9.050 .000,-$ & $(5.950 .000)$ \\
\hline Jumlah & $109.230 .000,-$ & $52.936 .000,-$ & $56.294 .000,-$ \\
\hline
\end{tabular}

Sumber : Data Primer Diolah, 2014. 
Dari Tabel 5. dapat diketahui bahwa dari lima belas kelompok usaha, terdapat delapan (48 kelompok yang mengalami kerugian. Total pengeluaran dari kelompok ini sebesar Rp 109.230.000,- (seratus Sembilan juta duaratus tiga puluh ribu rupiah). Sedangkan rata-rata pengeluaran Rp 13.653.750,-(tiga belas juta enam ratus lima puluh tiga ribu tujuh ratus lima puluh rupiah). Dana yang digunakan untuk membiayai usaha produktif, mendatangkan pendapatan bagi kelompok sebesar Rp 52.936.000,-(lima puluh dua juta Sembilan ratus tiga puluh enam ribu rupiah). Rata-rata pendapatan kelompok sebesar Rp 6.617.000,-(enam juta enam ratus tujuh belas ribu rupiah).

Data di atas dapat diketahui pula bahwa pengeluaran sebesar Rp 109.230.000,- jika dibandingkan dengan pendapatan sebesar Rp 52.936.000, maka kondisi kelompok kelompok usaha ini mengalami kerugian. Total kerugian yang dialami sesuai tabel 5 di atas berjumlah Rp 56.294.000,- . Rasio pendapatan dibandingkan dengan modal yang digunakan sebesar 1 : 0,48 (48\%). Hal ini memberikan pengertian bahwa setiap Rp 1 yang dikeluarkan untuk membiayai usaha, hanya mendatangakan penerimaan sebesar Rp 0,48 . Rasio kerugian adalah 1 : $0,5(51 \%)$. Hal ini memiliki pengertian bahwa setiap Rp 1 modal yang dikeluarkan tidak dapat mendatangkan keuntungan melainkan mengurangi modal sebesar Rp 0,5.

\subsection{Pembahasan}

Kesejahteraan rakyat selalu menjadi focus perhatian seorang pemimpin dalam pemerintahannya. Hal ini merupakan upaya perwujudan cita-cita bangsa sebagaimana tertuang di dalam Pembukaan Undang-Undang Dasar 1945 yakni mewujudkan masyarakat yang adil dan makmur.

Berbagai program ditetapkan pemerintah sebagai strategi untuk mewujudkan cita-cita bangsa dan perlu mendapaat dukungan dari masyarakat melalui respon balik atau implementasi program di dalam masyarakat. Respon positif dari masyarakat terhadap program pemerintah dan melaksanakannya dengan penuh tanggung jawab akan menghasilkan efektifitas dan efisiensi. Efektif artinya penggunaan dana dapat membuahkan hasil (Kamus besar bahasa Indonesia) berupa penerimaan atau keuntungan. Efisiensi artinya dana bantuan yang diberikan harus dikelolah secara baik sesuai rencana, tepat sasaran, dan baik hasilnya.

Dana bantuan yang digulirkan Pemerintah Daerah melalui program Demam Anggur Merah, secara keseluruhan ada manfaat. Hal ini dapat dilihat pada tabel 3 di atas. Keuntungan yang diperoleh cukup positif artinya ada manfaat dana yang digulirkan untuk kepentingan masyarakat itu sendiri.

Dari lima belas kelompok yang menerima dana bantuan hanya tujuh kelompok berhasil menggunakannya dengan baik sehingga memperoleh keuntungan, walalupun tidak seberapa besar. Ada beberapa kelopompok usaha yang cukup produktif dalam memanfaatkan modal. Kelompok yang memperoleh keuntungan diatas sepuluh juta selama setahun berjumlah 2 kelompok $(28,57 \%)$. Kelompok yang memperoleh keuntungan diatas lima juta dan dibawah sepuluh juta berjumlah 2 kelompok $(28,57 \%)$. Kelompok yang memperoleh keuntungan diatas satu juta dan dibawah lima juta berjumlah 3 kelompok $(42,86 \%)$.

Keuletan dalam bekerja tentu akan memberikan hasil yang baik. Sebaliknya jika program kerja tidak dilaksanakan dengan baik dan ulet tentu hasilnya tidak sesuai yang diharapkan. Jika demikian maka kesejahteraan masyarakat itu sendiri tidak akan mungkin meningkat. Dengan demikian dapat menimbulkan persepsi negative terhadap program Demam (Anggur Merah) ini. Perlu disadari oleh seluruh komponen lapisan masyarakat bahwa program bantuan seperti Anggur Merah ini, justeru masyarakat yang menjadi pelaku, sedangkan pemerintah hanya menawarkan program bantuan dan mengawasi pelaksanaannya.

Program kerja pemerintah propinsi Nusa Tenggara Timur , terutama Anggur Merah, sesungguhnya sangat membantu masyarakat kecil di pedesaan. Apabila masyarakat menyikapi dengan baik dan menjalankan dengan kesadaran akan perbaikan ekonominya, tidaklah mustahil pasti akan ada perubahan dalam meningkatkan taraf hidupnya. Dengan demikian anggota kelompok harus memiliki sifat hasil wirausahawan yang mampu melihat ke depan yang artinya bukan melamun kosong melainkan melihat berfikir dengan penuh perhitungan (Buchari Alma, 2001). Dengan demikian seorang wira usaha bekerja ekonomis dan efisien yang berarti melakukan kegiatannya dengan gaya smart (cerdas, pintar dan bijak) untuk mencapai hasil maksimal.

Operasinya kelompok usaha produktif yang menggunakan dana bantuan pemerintah, tidak semuanya berjalan mulus atau dengan kata lain tidak semua memperoleh keuntungan melainkan ada yang mengalami kerugian. Rugi/laba artinya hasil dari proses mempertemukan secara wajar antara semua penghasilan dengan semua biaya dalam periode tertentu (Supryono, 1999). Jika penghasilan lebih besar usaha memperoleh laba, sebaliknya jika penghasilan lebih kecil maka kelompok usaha mengalami kerugian.

Hasil penelitian ini juga menunjukan bahwa ada delapan kelompok usaha yang kurang beruntung atau rugi. Kelompok yang mengalami kerugian diatas sepuluh juta berjumlah 2 kelompok, sedangkan kelompok yang mengalami kerugian diatas 5 juta namun dibawah 10 juta, berjumlah 3 kelompok $(37,5 \%)$. Sedangkan kelompok yang mengalami kerugian diatas 1 juta namun dibawa lima juta berjumlah 3 kelompok $(37,5 \%)$.

Permasalahan yang dihadapi kelompok usaha, sangat beraneka ragam menimbulkan usaha tidak berjalan sesuai dengan rencana. Adapun kendala yang menjadi penyebab kerugian antara lain ketidak cocokan antara satu anggota dengan anggota lain karena ada rasa curiga diantara anggota. Selain itu adanya cuaca buruk yang menimbulkan gagal panen, penggunaan dana tidak bersifat produktif melainkan bersifat konsumtif. Penggunaan modal untuk kepentingan pribadi, pinjaman tidak dikembalikan dengan alas an tidak punya uang, dan lainlain juga dapat mengurangi modal atau dana bantuan.

Modal bantuan seharusnya dikembalikan agar dapat digulirkan kepada masyarakat yang lain. Hal ini bisa teratasi jika ada kerja sama yang baik antara pihak pemerintah dengan para kelompok. Seharusnya perlu ada pendampingan yang intensif untuk memberikan pemahaman kepada seluruh anggota kelompok tentang manfaat dana bantuan. Sebaliknya anggota kelompok juga seharusnya menyadari akan pentingnya pengelolaan keuangan secara efektif efisien.

Tabel 6. Data Tingkat Penggunaan Dana Bantuan, Pendapatan dan Laba/Rugi

\begin{tabular}{clccc}
\hline No & $\begin{array}{c}\text { Nama } \\
\text { Kelompok }\end{array}$ & $\begin{array}{c}\text { Tingkat } \\
\text { Penggunaan }\end{array}$ & Pendapatan & Laba/(Rugi) \\
\hline 1 & Gemilang & Tinggi & $44.000 .000,-$ & $34.000 .000,-$ \\
2 & Sabar Subur & Sedang & $35.000 .000,-$ & $7.000 .000,-$ \\
3 & Jaya Neonbat & Tinggi & $13.000 .000,-$ & $(7.000 .000)$ \\
4 & Sadi Sodak & Tinggi & $24.000 .000,-$ & $4.000 .000,-$ \\
5 & Moenfeu & Tinggi & $5.000 .000,-$ & $(7.000 .000)$ \\
6 & Hidup Baru & Tinggi & $4.040 .000,-$ & $(10.960 .000)$ \\
7 & Tani Mandiri & Tinggi & $4.000 .000,-$ & $(22.250 .000)$ \\
8 & Mekar Sari & Tinggi & $17.200 .000,-$ & $6.700 .000,-$ \\
9 & Nekmese & Tinggi & $50.000 .000,-$ & $15.000 .000,-$ \\
10 & Vatikan & Rendah & 1.500 .000 & $(1.500 .000)$ \\
11 & Mekar Pangan & Sedang & $9,700.000,-$ & 1.200 .000 \\
12 & Besahoma & Sedang & $7.700 .000,-$ & $(280.000)$ \\
13 & Seruni & Tinggi & $8.646 .000,-$ & $(1.354 .000)$ \\
14 & Tafenkuan & Tinggi & $9.050 .000,-$ & $(5.950 .000)$ \\
15 & Mawar Saron & Tinggi & $16.500 .000,-$ & $1.500 .000,-$ \\
Sumber $:$ Data Primer Diolah, 2014. & &
\end{tabular}

Dari Tabel 6. dapat diketahui bahwa kelompok yang menggunakan dana bantuan semua atau dalam kategori tinggi sebanyak 11 (sebelas) kelompok $(73,33 \%)$. Tidak semua kelompok mendapat keuntungan walaupun modal bantuan semuanya digunakan. Sebanyak 6 (enam) kelompok $(54,54 \%)$ yang menderita kerugian atau dapat dikatakan bahwa pengelolaan dana bantuan tidak efisien. Sedangkan 5 (lima) kelompok $(45,46 \%)$ memperoleh keuntungan atau dapat dikatakan bahwa pengelolaan dana bantuan efisien.

Kelompok yang menggunakan dana bantuan dalam kategori sedang berjumlah 3 (tiga) kelompok. Ketiga kelompok tersebut yang memperoleh keuntungan sebanyak 2 (dua) kelompok $(66,67 \%$ ) atau dapat dikatakan bahwa pengelolaan dana bantuan efisien. Sedangkan satu kelompok yang lain $(33,33 \%)$ menderita kerugian, atau tidak efisien pengelolaan dana bantuan. Selain kedua kelompok pengguna dana bantuan di atas (kategori tinggi dan sedang), masih ada kelompok yang dana bantuannya tidak digunakan secara keseluruhan bahkan tidak sampai $50 \%$ berjumlah 1 (satu kelompok)

Alasan mengapa kelompok tidak menggunakan dana bantuan seluruhnya karena banyak anggota kelompok yang apatis atau menghilang begitu saja tanpa alasan dan tidak diketahui alamat tempat tinggalnya. Selain itu ada banyak factor yang menyebabkan tidak digunakan secaraa baik modal bantuan karena paraa anggota kelompok tidak saling mendunkung satu sama lain melainkan menaruh curiga diantara anggota kelompok. Alasan lain adalah beberapa anggota keolompok sakit dan urusan keluarga sangat mendesak sehingga dana bantuan digunakan untuk hal-hal yang tidak produktif.

\section{Simpulan}

Respon masyarakat terhadap program bantuan pemerintah melalui program Demam Anggur Merah sangat tinggi. Hal ini terlihat dari jumlah kelompok yang dibentuk untuk menerima dana bantuan. Jumlah kelompok sebanyak lima belas kelompok. Banyak kelompok usaha produktif yang terbentuk untuk memanfaatkan dana bantuan. Terhadap penggunaan dana, hanya 7 kelompok yang lebih efisien dan efektif mengelolanya sehingga dapat memberikan keuntungan. Sedangkan 8 kelompok kurang kosentrasi dan pengelolaan modal tidak efisien dan tidak efektif sehingga mengalami kerugian. Namun jika pendapatan kelompok secara keseluruhan dibandingkan dengan pengeluaran kelompok secara keseluruhan terdapat laba atau surplus pendapatan. Dengan demikian dapat dikategorikan pengelolaan dana bantuan dalam kategori efisien.

\section{Pustaka}

Alma Buchari, 2001. Kewirausahaan., Cetakan ketiga. Penerbit CV. Alfabeta. Bandung.

BPS dan BAPPEDA TTU, 2005. Timor Tengah Utara Dalam Angka Tahun 2004/2005, BPS TTU, Kefamenanu.

Peraturan Gubernur Nusa Tenggara Timur Nomor 33 Tahun 2010 Tentang Pedoman Pembangunan Desa/Kelurahan Mandiri Anggur Merah Provinsi Nusa Tenggara Timur. Kupang.

Supryono R.A.1999. Akuntansi Biaya, Pengumpulan Biaya dan Penentuan Harga Pokok, Edisi 2. Penerbit BPFE Yogyakarta. 